\title{
MEASURING THE IMPACTS OF GOODS AND SERVICES TAX (GST) AND SALES AND SERVICES TAX (SST) ON THE COST OF PRODUCTION IN MALAYSIA: AN INPUT-OUTPUT PRICE MODEL ANALYSIS
}

\author{
SITI NUR'AMALINA SYEDDIN*, AZMAN HASSAN, CHAKRIN UTIT, MOHD YUSOF \\ SAARI AND JUDHIANA ABD GHANI
}

School of Business and Economics, Universiti Putra Malaysia, Malaysia

*Corresponding author: nuramalina071@gmail.com

Submitted final draft: 8 October $2020 \quad$ Accepted: 29 November 2020

http://doi.org/10.46754/jbsd.2021.03.001

\begin{abstract}
The Malaysian government has decided to re-introduce the Sales and Services Tax (SST) to replace the Goods and Services Tax (GST). This decision is expected to reduce the rate of inflation, however, it still leaves the members of industries and the public with more questions regarding its impacts on the cost of production. To address this concern, this study is structured to measure the impacts of GST and SST systems on the cost of production in Malaysia. To achieve this objective, an Input-Output price modelling technique is applied. The application of this model takes into consideration the different tax rates under both the GST and SST systems on 124 economic sectors in Malaysia. Results from the analysis suggest that GST has the tendency to reduce the cost of production in the economy while SST drives the cost increment. Meanwhile, these 124 economic sectors are classified into five broad economic sectors and the findings show that manufacturing sectors are mostly affected by these consumption taxes. It is noted that, this finding is derived based on the assumption that only the consumption tax system will affect the cost of production without considering the impacts of other external factors such as subsidy rationalisation, currency depreciation, minimum wage and market structure.
\end{abstract}

Keywords: Consumption tax structures, cost of production, Input-Output analysis

\section{Introduction}

On the $1^{\text {st }}$ of April 2015, the Malaysian government introduced the Goods and Services Tax (GST) system as a measure to broaden the consumption tax base. The introduction of GST has replaced the Sales Tax and Services Tax system that were introduced in February 1972 and March 1975, respectively. Through GST, Malaysia become the eighth member in the ASEAN community that implemented such a system following Indonesia that started its implementation in 1984, Thailand (1992), Singapore (1993), Philippines (1998), Cambodia and Vietnam (1999) and Laos (2009).

The government's decision to implement GST is justified by its capability to increase the economic efficiency (Hassan et al., 2016). Specifically, we can view the efficiency in three perspectives. First, GST is capable of reducing the cost of production. Theoretically, the cost of production under the GST system is expected to be lower since businesses are now entitled to claim their intermediate input costs along the supply chain. Second, since the businesses are entitled to claim their input costs, it is expected that the number of business registration would increase. In return, the government can reduce the number of informal businesses that are not registered with the authorities. Third, GST is regarded as a more equitable consumption tax system as it taxes every producer equitably along the supply chain.

Despite its role to increase the economic efficiency, the literature on this has provided clear evidences that GST may contribute towards inflationary episodes. The study that was conducted following the implementation of GST in Canada showed that the system has the 
tendency to increase the price level between $1.5 \%$ to $2.0 \%$, while the study in Hungary concluded that the increase of the GST rate by $3.0 \%$ will result in the inflation rate of $2.1 \%$ (Dungan \& Wilson, 1989; Gabriel \& Reiff, 2010). Based on a study conducted in Singapore by Jenkins and Khadka (1998), the implementation of GST in this country has induced the increment of the inflation rate to $3.6 \%$.

Based on the inflationary episodes in Malaysia, the government has decided to reintroduce the Sales and Services Tax (SST) system effective on September 2018. The decision has marked Malaysia as the first country that has replaced the GST system with the former consumption tax system. Although this decision is expected to reduce the inflation rate, it still leaves the members of the industries and the public with more questions regarding its impacts on the cost of production which will reflect the future cost of living. These consumption taxes would require the average price changes of consumer goods and services to be relative to the cost of productions. Therefore, would the reintroduction of SST contribute to diverse impact on the cost of production compared to GST?

To address this concern, this study is structured to measure the different impacts of GST and SST systems on the cost of production in Malaysia. To achieve this objective, the Input-Output price modelling technique is applied. The application of this model takes into consideration the different tax rates under both the GST and SST systems. It is also worth to emphasise, that the scope of this study is limited only to the impacts of the GST and SST systems. The study excludes the possible impacts from other external factors that might influence the cost of production such as the minimum wage legislation, crude oil price movement and currency depreciation.

This study provides two major contributions to the body of literature. First, the study updates the outcome of the study by Hassan et al. (2016) by comparing it with the impact of SST. The latest information related to the tax rates under the GST and SST systems is used in the modelling activities. Second, the study provides the results for all 124 economic sectors in Malaysia. With the detailed results, we may observe the impacts of GST and SST on all individual sectors. This study is structured into five sections.

- Section 2 summarises the findings from the previous literature.

- Section 3 details the methodological approach and the data used in the study.

- Section 4 discusses the results derived from the analysis.

- Section 5 provides the concluding remarks.

\section{Literature Review}

This section provides important findings from the literature which inform on the research gaps in the area of consumption tax structures. Based on the literature survey, this study discovered two main research gaps which provide the novelty aspects of this study. First, there is no study in the literature that analyses the government decision to replace the GST with SST system. The existing studies only focus on the impacts of consumption tax reforms from SST to GST. Second, consumption tax structure studies in Malaysia are highly concentrated on the application of partial equilibrium techniques. As far as the economic impacts are concerned, an applied general equilibrium analysis, such as an Input-Output price model, is more appropriate to be used. The following paragraphs detail the literature survey.

A range of empirical studies has been conducted to examine the economic and social impacts of different consumption tax structures. The scope of the studies ranges from the national level, to specific regional and local levels. For consumption tax structures itself, GST and SST, are commonly found in empirical findings from studies around the world, especially in developing and developed countries (see, for example, Olatunji, 2009; Keen \& Lockwood, 2010; Alm \& El-Ganainy, 2013; Gupta, 2014).

In the case of Malaysia, recent studies on consumption tax structures include a number 
of works by Ramli et al. (2015), Sanusi et al. (2015), Hassan et al. (2016), Ling et al. (2016), Loganathan et al. (2017) and Asmuni et al. (2017). These are the national and local level studies that emphasise on the governance, compliance and acceptance aspects of GST. These studies, however, were only on the impacts of GST implementation without considering the possibilities of the government re-introducing the SST system. As a result of these literature gaps, this study is able to provide useful insights into the expected impacts of cost of production from the different consumption tax systems.

For other countries, empirical evidences for the impacts of consumption tax system are abundant. These include the works by Matthews and Lloyd-Williams (2000), Emini (2000) and Smith et al. (2011). Among these studies, Smith et al. (2011) revealed that the implementation of GST helps to reduce government's administrative costs as the revenue increases in European countries. The findings seem to be consistent with Matthews and Lloyd-Williams (2000) who reported that the increase in revenue tended to promote the economic efficiency.

In terms of methodology, studies in Malaysia are mostly conducted using partial equilibrium techniques that are based on the econometric modelling approaches. Taha and Loganathan (2008), for example, employed the vector autoregression model to study the causality between tax revenue and government spending. Another study by Taha et al. (2018) also utilised the econometric modelling approach to look at the nexus between tax reform, financial development and economic recovery. Meanwhile, studies by Ishak et al. (2015) and Shaari et al. (2015) employed the survey technique.
Specifically, several relevant studies by researchers on GST in Malaysia used econometric method and survey technique for their methodology. For instance, Ling et al. (2016) analysed the impact and the correlation of GST between consumer price index (CPI), aggregate consumption, revenue and welfare adopted the multiple regression analysis. Meanwhile, Palil and Ibrahim (2011) and Shaari et al. (2015) used a questionnaire survey to recognise the response of society towards GST using the primary data. However, the application of the Input-Output price model to study the consumption tax reforms in Malaysia is limited, with the exception of Hassan et al. (2016). None of the studies used Input-Output price model to study the impacts of consumption tax structures. This constitutes another literature gap that this study aims to contribute to scientific knowledge.

\section{Research Method}

\section{Introduction}

This study employs an Input-Output modelling technique as the main methodological approach. Input-output is frequently utilised by researchers for impact analysis. The technique is chosen due to its capability to capture the interdependency aspect for economic sectors along their supply chain. Among the list of studies that has utilised this type of methodology in Malaysia are by Maji et al. (2017), Akhir et al. (2018) and Saari et al. (2018).

In specific terms, this study utilises an Input-Output price modelling technique. Figure 1 details the methodological framework that is used in this study. This framework is adapted from the study by Hassan et al. (2016) and is improvised by adding in the element of SST. 


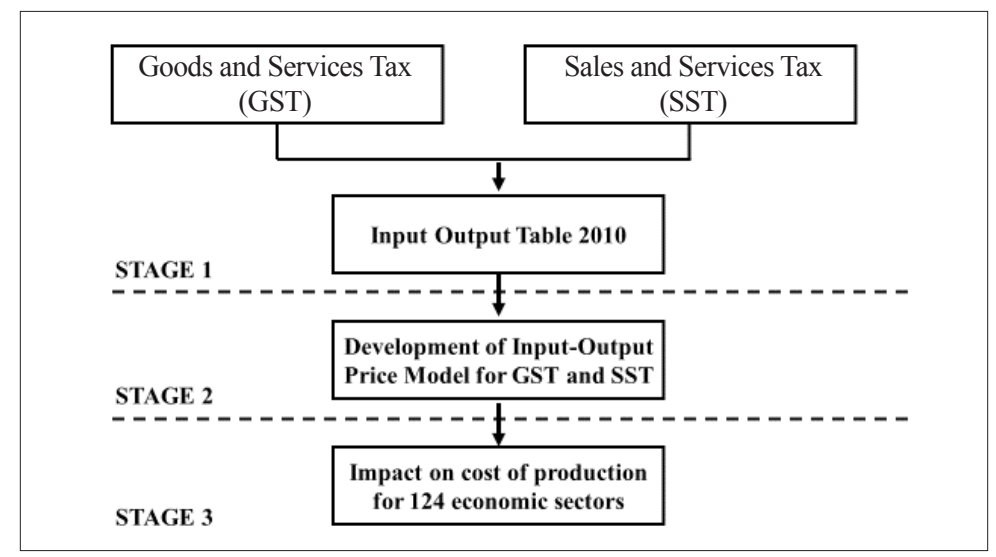

Figure 1: Methodological framework for measuring the impacts of GST and SST

Based on Figure 1, the framework can be summarised into three stages.

i. The first stage identifies the GST and SST variable in the input-output table. Using the 2010 national input-output table, the variable can be found at the row of "taxes on products". In general, this variable refers to the amount of consumption tax paid by the economic sectors to the government.

ii. Second, the Input-Output price model needs to be developed. The model will take into account the different tax rates available under the GST (standard rate, zero-rated and exempted) and SST (6\% for services and 5\% or $10 \%$ for sale of goods) system.

iii. In the third stage, the impacts of GST and SST tax systems on cost of production are calculated. The results are detailed for all 124 economic sectors.

\section{Input-Output Price Model}

The development of the Input-Output price model is assisted by the availability of the 2010 national input-output table. This table is published by the Department of Statistics Malaysia (2014) and consists of 124 economic sectors. Each sector in this table is represented by a group of economic activities that are classified based on the Malaysian Standard Industrial Classification (MSIC 2008). As previously mentioned, this study adapted the methodological framework by Hassan et al. (2016). Thus, the Input-Output price model described in this subsection shares similar characteristics.

To better understand the development process of the Input-Output price model, we may start by describing the interdependency aspect of the economy using the following equation.

$$
\mathrm{x}=\sum \mathrm{Z}+\mathrm{f}+\mathrm{e}
$$

where, $\mathrm{x}$ is the total output vector. Specifically, $\mathrm{x}$ is formed through the summation of output that is consumed as an intermediate input Z (i.e., output of sector A that is used as intermediate input by sector B), output consumed by final demand, $f$ (private consumption, government consumption and investment) and exports, e. In a standard model, equation (1) can be transformed into:

$$
\mathrm{x}=\mathrm{Ax}+(\mathrm{f}+\mathrm{e})=(\mathrm{I}-\mathrm{A})^{-1}(\mathrm{f}+\mathrm{e})=\mathrm{L}(\mathrm{f}+\mathrm{e})
$$

where $I$, is the identity matrix, $\mathrm{A}\left(\mathrm{A}=\mathrm{Z} \hat{\mathrm{x}}^{-1}\right)$ is the input-output coefficient matrix, and $\mathrm{L}$ is the Leontief inverse matrix. For each sector, the Leontief inverse matrix coefficient represents the total output that is required to fulfil each unit of final demand. Equation (2) is also known as an Input-Output quantity model. This model assumes that only quantity changes, while price is fixed.

As for the price model or also known as the cost-push model, it is useful to analyse the impacts from the movement of prices and costs 
that can be linked to taxes, import duty and labour income. This model assumes that the quantity is fixed and prices and costs are adjustable. The model can be summarised as follows:

$$
\begin{aligned}
\mathrm{p} & =\mathrm{A}^{\prime} \mathrm{p}+\mathrm{l}+\mathrm{v}+\mathrm{m}+\mathrm{t}=\left(\mathrm{I}-\mathrm{A}^{\prime}\right)^{-1}(1+\mathrm{v}+\mathrm{m}+\mathrm{t}) \\
& =\mathrm{L}^{\prime}(1+\mathrm{v}+\mathrm{m}+\mathrm{t})
\end{aligned}
$$

where, $\mathrm{p}$ is a vector of normalised prices (price is adjusted to equal 1 at baseline), $\mathrm{A}^{\prime}$ is the transposed input-output coefficient matrix and $1, \mathrm{v}, \mathrm{m}$ and $\mathrm{t}$ are the column vectors for labour income coefficient (income per unit of output), capital income coefficient (capital income per unit of output), import coefficient (import per unit of output) and indirect taxes coefficient (indirect taxes per unit of output), respectively. In equation (3), $1, \mathrm{v}, \mathrm{m}$ and $\mathrm{t}$ are exogenous variables. As we set $p$ as unity, thus the equation (3) can be simplified as the following:

$$
\mathrm{p}=\mathrm{L}^{\prime}(1+\mathrm{v}+\mathrm{m}+\mathrm{t})
$$

Through equation $4,1, \mathrm{v}$ and $\mathrm{m}$ are assumed to be fixed and only $t$ is adjusted according to the GST and SST rates. It means that only $t$ causes change in $\mathrm{p}$. In this model, when there is no change in the indirect taxes, the represented indirect taxes coefficient equals 1 . Meanwhile, if indirect taxes have changed, the changes can be translated into: $\Delta \mathrm{t}=\mathrm{t} \otimes \Delta \mathrm{p}_{\mathrm{t}}$, where $\otimes$ refers to Hadamard product, which simply means cell-by-cell multiplication and $\Delta \mathrm{p}_{\mathrm{t}}$ refers to changes in indirect taxes. At the baseline, $\mathrm{p}_{t}$ equals to 1 and if the tax rate increases by $10 \%$, then $\mathrm{p}_{t}$ will become 1.10 . Using the price passthrough concept, the increase in the cost of production due to the increase in tax rate will be translated into the increase in the price of goods and services. Therefore, the equation can be rewritten as the following:

$$
\Delta \mathrm{P}=\mathrm{L}^{\prime}(\mathrm{I}+\mathrm{v}+\mathrm{m}+\Delta \mathrm{t})
$$

For GST, the modification on equation (5) is needed since the equation is modelled only for standard tax rate, but in practice, GST rates consist of $6 \%$, zero-rated and exempted-rate.
Each category of GST rates gives differential effects on the cost of production. Hence, the Leontief inverse matrix is modified according to the GST rates and modelled as in equation 6 . For SST, the same process is also undertaken to address the different tax rates for the sale of services and sales of goods.

$\Delta p=\left(I-A^{\prime} \hat{B}\right)^{-1}(1+v+m+\Delta t)=L^{\prime}(1+v+m+\Delta t)$

where, $\hat{B}$ represents the diagonal matrix used to modify the input-output coefficient, A' according to the GST and SST rates. Apart of $A^{\prime}$, indirect tax coefficient, $t$, is also adjusted for the impacts of GST as this consumption tax is based on value added. The complete model of the impacts of GST and SST on the cost of production is based on the following equation. For more exposition on the model, please refer to Hassan et. al. (2016).

$$
\Delta p=\left(I-A^{\prime} \hat{B}\right)^{-1}(1+v+m+u)=L^{\prime}(1+v+m+u)
$$

\section{Data Sources}

There are three types of data utilised in this study. The first data comes from the 2010 national input-output table that is derived from the Department of Statistics Malaysia (2014). The input-output analyses are based on the publicly available input-output table as of 2010 when this study was conducted. Therefore, there were arguments on the validity of using the same data set for this analysis with the available input-output table for Malaysia is for reference year 2010 (released in 2014). However, from the perspective of national accounting, the timelag issue with input-output tables is negligible because there are strong evidences proving there are only marginal changes in the economic structure over the periods of five to ten years. Thus, the employment of input-output table 2010 for economic analysis before 2018 is valid since the latest input-output table is released at the end of 2018. This table provides the information that details the transaction among the different economic sectors and also their relationship with final consumers. In total, the table covers 
124 economic sectors. The second data source is the output breakdown by economic activities that are derived from the 2011 Economic Census Report (Department of Statistics Malaysia, 2012). Output breakdown by economic activities is needed to provide the information during the development process of the Input-Output price model. Finally, the information on the tax rates for different goods and services under GST and SST systems are derived from the Royal Malaysian Customs Department (2015 and 2018). The list is required to classify the goods and services based on their tax rate.

\section{Results and Discussion}

Discussion in Section 3 clearly mentioned that the impacts of GST and SST systems on the cost of production in Malaysia are measured using the Input-Output price model. However, before the price models are developed, several data processing stages are conducted. As the starting point, the list of taxable goods and services under GST and SST systems are harmonized to the list of available economic activities in the economy that are classified using MSIC 2008. Matching is required as each economic activity has a different tax rate. A sector is represented by a group of economic activities and it means that one sector may consist of more than one tax rate. Once the price models are developed, the impacts of the consumption tax system on the cost of production are measured and the results are presented in the following subsections.

\section{Impacts on Cost of Production by Broad Economic Sectors}

This section compares the impacts of GST and SST on cost of production by broad economic sectors. From the total of 124 sectors, the average changes in the cost of production in Agriculture, Mining and Quarrying, Manufacturing, Construction and Services sector are calculated. Findings from the analysis are given in Table 1.
Table 1: Average impacts of GST and SST on cost of production by broad economic sectors in percentage

\begin{tabular}{lcc}
\hline \multicolumn{1}{c}{ Sector } & GST & SST \\
\hline Agriculture & -0.54 & 3.08 \\
Mining \& Quarrying & -0.10 & 1.23 \\
Manufacturing & -0.56 & 14.14 \\
Construction & -0.50 & 12.24 \\
Services & -0.80 & 9.50 \\
\hline Total Economy & -0.63 & 10.83 \\
\hline
\end{tabular}

In total GST is found to reduce the total cost of production in the economy by $0.63 \%$. The highest decrease can be observed in the services sector with the estimated reduction by $0.80 \%$ and manufacturing by $0.54 \%$. This result is in line with the findings highlighted in Hassan et. al. (2016) where the GST is also found to reduce the level of cost of production. Nevertheless, these findings are not being reflected in reality during the GST implementation period as price levels are partly determined by external factors such as subsidy rationalisation, currency depreciation, minimum wage and market structure.

Meanwhile, for the re-introduction of the SST, the tax structure is prone to increase the total cost of production by $10.83 \%$. The major reason behind the sharp rises in the price level is due to the larger tax rate levied on manufacturers and service providers. The largest increment can be found in the Manufacturing sector with the incremental level of $14.14 \%$ and construction sector with $12.24 \%$. However, it is worth to be noted that the estimated impacts for SST as presented in Table 1 are based on the assumption that all Manufacturing and Services subsectors are taxed evenly according to their rates.

\section{Total Impacts on Cost of Production}

Based on the discussion from the previous subsection, we may further expand the results to cover all 124 economic sectors. The expansion of the results will enable us to identify the list of sectors that are affected the most from the implementation of GST and the re-introduction of the SST. The results for five broad economic sectors are tabulated in Table 2 until Table 6. 
Table 2: Impacts of GST and SST on the cost of production in percentage for Agriculture

\begin{tabular}{llcc}
\hline & Sector & GST & SST \\
\hline 1 & Paddy & -0.12 & 1.03 \\
2 & Food Crops & -0.19 & 1.60 \\
3 & Vegetables & -0.39 & 2.11 \\
4 & Fruits & -0.29 & 1.44 \\
5 & Rubber & -0.56 & 3.47 \\
6 & Oil Palm & -0.37 & 2.12 \\
7 & Flower Plants & -0.32 & 1.59 \\
8 & Other Agriculture & -0.43 & 2.38 \\
9 & Poultry Farming & -1.12 & 5.81 \\
10 & Other Livestock & -0.88 & 5.06 \\
11 & Forestry and Logging & -0.72 & 3.89 \\
12 & Fishing & -0.82 & 4.94 \\
\hline Total Economy & -0.52 & 2.95 \\
(Weighted Average) & & \\
\hline
\end{tabular}

The result given in Table 2 shows the impacts of GST and SST on cost of production in Agriculture. Top-three sectors that received the most benefits from the implementation of GST include Poultry Farming, Other Livestock and Fishing. Their respective reduction in total cost of production is $1.12 \%, 0.88 \%$ and $0.82 \%$. In contrast, SST tends to increase all sectors in Agriculture. The largest increment can also be recorded by Poultry Farming, Other Livestock and Fishing with their respective cost increment of $5.81 \%, 5.06 \%$ and $4.94 \%$.

In the meantime, Table 3 illustrates the impacts of GST and SST on cost of production in Mining and Quarrying. As can be seen in the table, all economic sectors acknowledged reduction from the implementation of GST. However, SST tends to increase in all the economic sectors in Mining and Quarrying.

Table 3: Impacts of GST and SST on the cost of production in percentage for Mining and Quarrying

\begin{tabular}{llcc}
\hline & Sector & GST & SST \\
\hline 13 & Crude Oil and Natural Gas & -0.06 & 1.16 \\
14 & Metal Ore Mining & -0.69 & 2.15 \\
\hline
\end{tabular}

\begin{tabular}{llcc}
\hline \multicolumn{1}{c}{ Sector } & GST & SST \\
\hline $15 \quad \begin{array}{l}\text { Stone Clay and Sand } \\
\text { Quarrying }\end{array}$ & -0.59 & 1.81 \\
$16 \quad$ Other Mining and Quarrying & -0.91 & 2.96 \\
\hline $\begin{array}{l}\text { Total Economy } \\
\text { (Weighted Average) }\end{array}$ & -0.56 & 2.02 \\
\hline
\end{tabular}

Next broad economic sectors are Manufacturing that is represented in Table 4. Both consumption taxes give different impacts on these economic sectors where GST tends to reduce the cost of production while SST significantly raises the cost of production of the economic sectors. In the case of GST, the cost of production of Meat and Meat Production, Bakery Products and Preservation of Seafood showed the highest cost of production reduction with total reduction of $5.08 \%, 4.24 \%$ and $3.66 \%$ respectively. Again, the results on the impact of SST shows the increment for all sectors in Manufacturing. The major increment can be noted by Rubber sectors which includes Rubber Processing, Rubber Gloves and Rubber Products by their respective cost increment of $19.60 \%$, $20.93 \%$ and $21.58 \%$.

Table 4: Impacts of GST and SST on the cost of production in percentage for Manufacturing

\begin{tabular}{llcc}
\hline & \multicolumn{1}{c}{ Sector } & GST & SST \\
\hline 17 & Meat and Meat Production & -5.08 & 17.94 \\
18 & Preservation of Seafood & -3.66 & 18.31 \\
& Preservation of Fruits and & -2.15 & 15.49 \\
& Vegetables & -2.94 & 17.07 \\
20 & Dairy Production & -0.64 & 17.54 \\
21 & Oils and Fats & -1.34 & 12.06 \\
22 & Grain Mills & -4.24 & 15.52 \\
23 & Bakery Products & -2.15 & 13.19 \\
24 & Confectionery & -2.73 & 14.95 \\
25 & Other Food Processing & -2.50 & 15.11 \\
26 & Animal Feeds & -1.03 & 11.74 \\
27 & Wine and Spirit & -2.12 & 15.30 \\
28 & Soft Drink & -1.39 & 12.07 \\
29 & Tobacco Products & -1.26 & 15.80 \\
\hline 30 & Yarn and Cloth & & \\
\hline
\end{tabular}




\begin{tabular}{|c|c|c|c|}
\hline & Sector & GST & SST \\
\hline 31 & Finishing of Textiles & -2.39 & 16.30 \\
\hline 32 & Other Textiles & -0.56 & 14.00 \\
\hline 33 & Wearing Apparel & -0.53 & 13.38 \\
\hline 34 & Leather Industries & -0.60 & 14.50 \\
\hline 35 & Footwear & -1.46 & 14.66 \\
\hline 36 & $\begin{array}{l}\text { Sawmilling and Planning of } \\
\text { Wood }\end{array}$ & -0.75 & 11.61 \\
\hline 37 & $\begin{array}{l}\text { Veneer Sheets, Plywood, } \\
\text { Laminated \& Particle Board }\end{array}$ & -0.61 & 13.19 \\
\hline 38 & $\begin{array}{l}\text { Builders' Carpentry and } \\
\text { Joinery }\end{array}$ & -0.59 & 15.17 \\
\hline 39 & $\begin{array}{l}\text { Wooden and Cane } \\
\text { Containers }\end{array}$ & -0.75 & 16.38 \\
\hline 40 & Other Wood Products & -1.31 & 15.36 \\
\hline 41 & $\begin{array}{l}\text { Paper and Paper Products } \\
\text { and Furniture }\end{array}$ & -0.89 & 14.58 \\
\hline 42 & Publishing & -0.26 & 13.85 \\
\hline 43 & Printing & -0.84 & 14.23 \\
\hline 44 & Petroleum Refinery & -0.12 & 11.22 \\
\hline 45 & Basic Chemicals & -0.53 & 15.87 \\
\hline 46 & Fertilizers & -0.55 & 15.27 \\
\hline 47 & Paints and Varnishes & -0.52 & 15.21 \\
\hline 48 & $\begin{array}{l}\text { Pharmaceuticals, Chemicals } \\
\text { \& Botanical Product }\end{array}$ & -0.37 & 12.60 \\
\hline 49 & $\begin{array}{l}\text { Soap, Detergents, Perfumes, } \\
\text { Cleaning \& Toilet } \\
\text { Preparations }\end{array}$ & -0.43 & 16.30 \\
\hline 50 & Other Chemicals Product & -0.41 & 16.40 \\
\hline 51 & Tyres & -0.64 & 16.59 \\
\hline 52 & Rubber Processing & -0.56 & 19.60 \\
\hline 53 & Rubber Gloves & -0.59 & 20.93 \\
\hline 54 & Rubber Products & -0.70 & 21.58 \\
\hline 55 & Plastics Products & -0.57 & 16.49 \\
\hline 56 & $\begin{array}{l}\text { Sheet Glass and Glass } \\
\text { Products }\end{array}$ & -0.59 & 15.86 \\
\hline 57 & Clay and Ceramic & -0.61 & 13.91 \\
\hline 58 & Cement, Lime and Plaster & -0.51 & 15.03 \\
\hline 59 & $\begin{array}{l}\text { Concrete \& Other Non- } \\
\text { Metallic Mineral Products }\end{array}$ & -0.66 & 16.90 \\
\hline 60 & Iron and Steel Products & -0.42 & 16.44 \\
\hline
\end{tabular}

\begin{tabular}{|c|c|c|c|}
\hline & Sector & GST & SST \\
\hline 61 & $\begin{array}{l}\text { Basic Precious and Non- } \\
\text { Ferrous Metals }\end{array}$ & -0.32 & 13.24 \\
\hline 62 & Casting of Metals & -0.33 & 13.80 \\
\hline 63 & Structural Metal Products & -0.44 & 15.59 \\
\hline 64 & $\begin{array}{l}\text { Other Fabricated Metal } \\
\text { Products }\end{array}$ & -0.50 & 15.08 \\
\hline 65 & Industrial Machinery & -0.44 & 14.25 \\
\hline 66 & General Purpose Machinery & -0.51 & 13.93 \\
\hline 67 & Special Purpose Machinery & -0.91 & 13.42 \\
\hline 68 & Domestic Appliances & -0.52 & 13.63 \\
\hline 69 & $\begin{array}{l}\text { Office, Accounting and } \\
\text { Computing Machinery }\end{array}$ & -0.36 & 11.97 \\
\hline 70 & $\begin{array}{l}\text { Electrical Machinery and } \\
\text { Apparatus }\end{array}$ & -0.43 & 14.63 \\
\hline 71 & Other Electrical Machinery & -0.62 & 12.42 \\
\hline 72 & Insulated Wires and Cables & -0.34 & 13.36 \\
\hline 73 & $\begin{array}{l}\text { Electric Lamps and Lighting } \\
\text { Equipment }\end{array}$ & -0.42 & 13.53 \\
\hline 74 & $\begin{array}{l}\text { Semi-Conductor Devices, } \\
\text { Tubes and Circuit Boards }\end{array}$ & -0.28 & 12.25 \\
\hline 75 & $\begin{array}{l}\text { TV, Radio Receivers \& } \\
\text { Transmitters \& Assoc. } \\
\text { Goods }\end{array}$ & -0.18 & 11.65 \\
\hline 76 & $\begin{array}{l}\text { Medical, Surgical and } \\
\text { Orthopaedic Appliances }\end{array}$ & -0.36 & 14.25 \\
\hline 77 & $\begin{array}{l}\text { Measuring, Checking } \\
\& \text { Industrial Process } \\
\text { Equipment }\end{array}$ & -0.26 & 12.84 \\
\hline 78 & $\begin{array}{l}\text { Optical Instruments and } \\
\text { Photographic Equipment }\end{array}$ & -0.27 & 12.40 \\
\hline 79 & Watches and Clocks & -0.40 & 13.77 \\
\hline 80 & Motor Vehicles & -0.08 & 8.19 \\
\hline 81 & Motorcycles & -0.23 & 12.75 \\
\hline 82 & $\begin{array}{l}\text { Building \& Repairing } \\
\text { of Ships \& Boats, } \\
\text { Manufacturing of Bicycles } \\
\text { \& Invalid Carriages }\end{array}$ & -0.64 & 16.22 \\
\hline 83 & Other Transport Equipment & -0.35 & 14.64 \\
\hline 84 & Other Manufacturing & -0.51 & 12.80 \\
\hline 85 & Repair \& Maintenance & -0.72 & 18.05 \\
\hline \multicolumn{2}{|c|}{$\begin{array}{l}\text { Total Economy } \\
\text { (Weighted Average) }\end{array}$} & -0.93 & 14.70 \\
\hline
\end{tabular}


The impacts of both consumption taxes in Construction cost of production illustrated in Table 5, where GST positively impacts the cost of production for all economic sectors for Construction with cost reduction. Yet, SST still gives the opposite impact on the cost of production for all the economic sectors in Construction as the results show the increment in the cost.

Table 5: Impacts of GST and SST on the cost of production in percentage for Construction

\begin{tabular}{llcc}
\hline & \multicolumn{1}{c}{ Sector } & GST & SST \\
\hline 86 & Residential & -0.43 & 12.53 \\
87 & Non-Residential & -0.44 & 12.38 \\
88 & Civil Engineering & -0.53 & 12.17 \\
89 & Special Trade Works & -0.60 & 11.81 \\
\hline Total Economy & -0.50 & 12.22 \\
(Weighted Average) & & \\
\hline
\end{tabular}

For Services sectors, the results from the impact of GST and SST are of similar pattern with other previous broad economic sectors in which the impact of GST tends to reduce the cost of production while SST is likely to increase the cost as shown in Table 6. For instance, the impact of GST mostly benefited the Education sector as the cost reduction for the sector is recorded at $2.73 \%$. Unlike SST, the most affected sector from SST is the Financial institution which indicated a cost increment of $12.34 \%$. The reduction in their cost of production is mainly due to the fact that their goods are levied with zero-rate GST.

Table 6: Impacts of GST and SST on the cost of production in percentage for Services

\begin{tabular}{|c|c|c|c|}
\hline \multicolumn{2}{|r|}{ Sector } & GST & SST \\
\hline 90 & Electricity and Gas & -0.26 & 8.61 \\
\hline 91 & Waterworks & -0.25 & 8.25 \\
\hline 92 & $\begin{array}{l}\text { Sewerage, Waste } \\
\text { Collection \& Remediation } \\
\text { Activities }\end{array}$ & -0.51 & 10.67 \\
\hline 93 & $\begin{array}{l}\text { Wholesale \& Retail Trade } \\
\text { and Motor Vehicle }\end{array}$ & -0.64 & 8.17 \\
\hline 94 & Accommodation & -0.40 & 10.97 \\
\hline
\end{tabular}

\begin{tabular}{|c|c|c|c|}
\hline \multicolumn{2}{|r|}{ Sector } & \multirow{2}{*}{$\begin{array}{l}\text { GST } \\
-1.15\end{array}$} & \multirow{2}{*}{$\begin{array}{r}\text { SST } \\
11.5\end{array}$} \\
\hline 95 & Restaurants & & \\
\hline 96 & Land Transport & -1.07 & 9.98 \\
\hline 97 & Water Transport & -0.54 & 10.84 \\
\hline 98 & Air Transport & -0.14 & 10.72 \\
\hline 99 & Other Transport Services & -0.67 & 11.56 \\
\hline 100 & $\begin{array}{l}\text { Port and Airport Operation } \\
\text { Services }\end{array}$ & -0.43 & 10.80 \\
\hline 101 & $\begin{array}{l}\text { Highway, Bridge and } \\
\text { Tunnel Operation Services }\end{array}$ & -0.20 & 7.88 \\
\hline 102 & Communications & -0.15 & 9.49 \\
\hline 103 & Publishing Activity & -0.55 & 10.01 \\
\hline 104 & Telecommunications & -0.22 & 11.10 \\
\hline 105 & $\begin{array}{l}\text { Cinema, Video and } \\
\text { Television Activity }\end{array}$ & -0.26 & 9.73 \\
\hline 106 & ICT \& Computer Services & -0.22 & 10.38 \\
\hline 107 & Banks & -1.35 & 9.45 \\
\hline 108 & Financial Institution & -1.04 & 12.34 \\
\hline 109 & Insurance & -0.73 & 9.23 \\
\hline 110 & Other Financial Institution & -1.26 & 11.30 \\
\hline 111 & Real Estate & -0.66 & 10.39 \\
\hline 112 & Ownership of Dwellings & -0.13 & 8.20 \\
\hline 113 & Rental and Leasing & -0.55 & 9.49 \\
\hline 114 & $\begin{array}{l}\text { Research and } \\
\text { Development }\end{array}$ & -0.23 & 7.05 \\
\hline 115 & Professional & -0.72 & 8.79 \\
\hline 116 & Business Services & -0.69 & 9.87 \\
\hline 117 & Public Administration & -1.32 & 9.46 \\
\hline 118 & Education & -2.73 & 7.50 \\
\hline 119 & Health & -0.67 & 9.81 \\
\hline 120 & Defence and Public Order & -0.60 & 10.85 \\
\hline 121 & $\begin{array}{l}\text { Other Public } \\
\text { Administration }\end{array}$ & -0.31 & 7.31 \\
\hline 122 & $\begin{array}{l}\text { Private Non-Profit } \\
\text { Institution }\end{array}$ & -1.53 & 8.39 \\
\hline 123 & $\begin{array}{l}\text { Amusement and } \\
\text { Recreational Services }\end{array}$ & -1.28 & 9.62 \\
\hline 124 & Other Private Services & -0.53 & 7.47 \\
\hline $\begin{array}{l}\text { Total } \\
\text { (Weis }\end{array}$ & $\begin{array}{l}\text { conomy } \\
\text { ted Average) }\end{array}$ & -0.69 & 9.63 \\
\hline
\end{tabular}


As previously discussed, GST reduces the total cost of production in the economy by $0.63 \%$, while SST drives the cost increment by $10.83 \%$. Although not all sectors are taxed under both of the system, the interdependency aspect that can be traced along the supply chain leads to changes in the cost of production in all sectors. In this case, the magnitude of the impacts depends entirely on the integration level between one sector to another. For example, both GST and SST systems clearly defined that the rice that is classified under Grain Mills sector is exempted from consumption tax, but the interaction between the sector with other sectors of the supply chain has channelled some the impact to this sector.

The outcome from this study is in-line with the result obtained from the survey conducted by the Federation of Malaysian Manufacturers (FMM) and the Malaysian Institute of Economic Research (MIER) (FMM \& MIER, 2019). The survey concludes that the re-introduction of SST has increased the cost of doing business by $10 \%$.

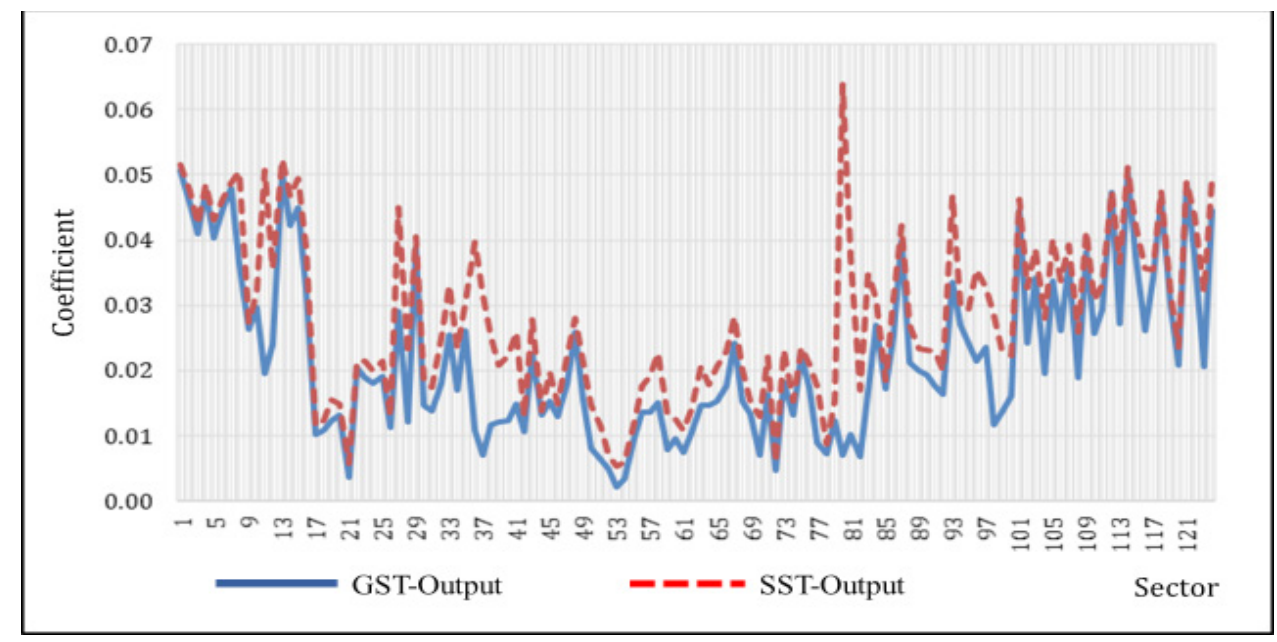

Source: Hassan et al. (2016)

Figure 2: Comparison of GST-output and SST-output coefficients

Specifically, the reason behind the sharp increase in the cost of production due to the implementation of SST can be directed towards its taxation process (Hassan et al., 2016). In practice, SST is levied based on output, while the GST is based on value added. Among other factors that contributed to the cost increment is higher SST rate for raw materials, components and services (FMM \& MIER, 2019). Additionally, the lack of clarity on the application of procedures for exemption also contributed to rising cost of production.

To better explain the impacts of GST and SST, Figure 2 gives the details on the difference between the GST and SST tax coefficients on output. The coefficients are derived by calculating the ratio of tax to output. In total,
Figure 2 clearly shows that the tax coefficients for GST are lower than the coefficients for SST, thus explaining why GST can drive down the cost of production.

\section{Conclusion}

This study documents the findings on the impacts of GST and SST systems on the cost of production in Malaysia. Based on the available dataset at the national level, the impacts are estimated using the Input-Output modelling technique. Findings reveal that GST has the tendency to reduce the cost of production. In contrast, SST is estimated to bring undesirable impacts for the cost of production. Despite the usefulness of the findings from this study, the results need to be interpreted cautiously as the study is subjected to a number 
of assumptions. Specifically, this study assumes that only consumption tax system determines the cost of production. This assumption leaves out other external forces for example: subsidy rationalisation, currency depreciation, minimum wage and market structure as constant.

For that reason, this study concludes that the impact of the re-introduction of SST is contrary to GST where the cost of production in each broad economic sector keeps increasing. As such, the re-introduced SST will erode the cost of production increase as the price of commodities is likely to inflate. The significant implications are by improving the tax structures with supplementary tax exemptions, especially on small medium sectors. The new adjustment of SST structures with exemption, especially for small business sectors, will help reduce the tax compliance costs. This would reduce administrative burdens for these business sectors and create a level playing field for businesses, regardless of where they are established in the country.

\section{Acknowledgements}

The authors are grateful for the comments from the reviewers in improving this manuscript. This research is part of a dissertation which was submitted as partial fulfilment to meet requirements for the degree of Doctor of Philosophy at Universiti Putra Malaysia.

\section{References}

Akhir, N. H. M., Ismail, N. W., \& Utit, C. (2018). Malaysian Batik Industry contribution analysis using direct and indirect effects of input-output techniques. International Journal of Business \& Society, 19(1), 181194.

Alm, J., \& El-Ganainy, A. (2013). Value-added taxation and consumption. International Tax and Public Finance, 20(1), 105-128.

Asmuni, S., Yusoff, S., \& Ses, N. S. M. (2017). Acceptance towards Goods and Services Tax (GST) among local business communities.
Journal of Emerging Economies \& Islamic Research, 5(4), 62-72.

Department of Statistics Malaysia. (2012). Economic Census 2011. Putrajaya: Department of Statistics Malaysia.

Dungan, D. P., \& Wilson, T. A. (1989). The proposed federal goods and services tax: Its economic effects under alternative labour market and monetary policy. Canadian Tax Journal, 37, 341-367.

Emini, C. A. (2000). Long run vs. short run effects of a value added tax: A computable general equilibrium assessment for Cameroon. Cahier de Recherchè, No. 0012.

Federation of Malaysian Manufacturers and Malaysian Institute of Economic Research. (2019, February 28). Poll: SST raises cost of doing business. Retrieved from https:// www.thestar.com.my/business/businessnews/2019/02/28/poll-sst-raises-cost-ofdoing-business/.

Gabriel, P., \& Reiff, A. (2010). Price setting in Hungary: A store-level analysis. Managerial and Decision Economics, 31, 161-176.

Gupta, N. (2014). Goods and Services Tax it's impact on Indian economy. International Research Journal of Commerce Arts and Science, 5(3), 126-133.

Hassan, A. A. G., Saari, M. Y., Utit, C., Hassan, A., \& Haron, M. (2016). Penggangaran impak CBP ke atas kos pengeluaran dan kos sara hidup di Malaysia. Jurnal Ekonomi Malaysia, 50(2), 15-30.

Ishak, N. I., Othman, M. H., \& Omar, M. F. (2015). Students' perception towards the newly implemented Goods and Services Tax (GST) in Malaysia. International Journal of Contemporary Applied Sciences, 2(6), 80-99.

Jenkins, G. P., \& Khadka, R. (1998). Valueadded tax policy and implementation in Singapore. International VAT Monitor, $9(2), 35-47$. 
Keen, M., \& Lockwood, B. (2010). The value added tax: Its causes and consequences. Journal of Development Economics, 92(2), 138-151.

Ling, S. C., Osman, A., Arman Hadi, A. B., Muhammad Safizal, A., \& Rana, S. M. (2016). Public acceptance and compliance on Goods and Services Tax (GST) implementation: A case study of Malaysia. Asian Journal of Social Sciences \& Humanities, 5(1), 1-12.

Ling, S. C., Osman, A., Muhammad, S., Yeng, S. K., \& Jin, L. Y. (2016). Goods and Services Tax (GST) compliance among Malaysian consumers: The Influence of price, government subsidies and income inequality. Procedia Economics and Finance, 35, 198-205.

Loganathan, N., Ismail, S., Streimikiene, D., Hassan, A. A. G., Zavadskas, E. K., \& Mardani, A. (2017). Tax reform, inflation, financial development and economic growth in Malaysia. Romanian Journal of Economic Forecasting, 20(4), 152-165.

Maji, I. K., Saari, M. Y., Habibullah, M. S., \& Utit, C. (2017). Measuring the economic impacts of recent oil price shocks on oil-dependent economy: Evidence from Malaysia. Policy Studies, 38(4), 375-391.

Matthews, K., \& Lloyd-Williams, J. (2000). Have VAT rates reached their limit?: An empirical note. Applied Economics Letters, 7(2), 111-115.

Olantunji, O. C. (2009). A review of value added tax (GST) administration in Nigeria. International Business Management, 2(4), 61-68.

Palil, M. R., \& Ibrahim, M. A. (2011). The impacts of Goods and Services Tax (GST) on middle income earners in Malaysia. World Review of Business Research, 1(3), 192-206.
Ramli, R., Palil, M. R., Hassan, N. S. A., \& Mustapha, A. F. (2015). Compliance costs of Goods and Services Tax (GST) among small and medium enterprises. Journal of Management, 45, 39-48.

Sanusi, S., Omar, N., \& Sanusi, Z. M. (2015). Goods and Services Tax (GST) governance in the Malaysian new tax environment. Procedia Economics and Finance, 31, 373379.

Saari, M. Y., Habibullah, M. S., Utit, C., \& Maji, I. K. (2018). Economic impacts of petroleum industry in states of Pahang and Terengganu. Jurnal Ekonomi Malaysia, 52(2), 149-161.

Shaari, N., Ali, A., \& Ismail, N. (2015). Student's awareness and knowledge on the implementation of Goods and Services Tax (GST) in Malaysia. Procedia Economics and Finance, 31, 269-279.

Smith, M. C., Islam, A., \& Moniruzzaman, M. (2011). Consumption taxes in developing countries- The case of Bangladesh GST. Working Paper no. 82, Centre for Accounting, Government and Taxation Research, Victoria University of Wellington, New Zealand.

Taha, R., \& Loganathan, N. (2008). Causality between tax revenue and government spending in Malaysia. The International Journal of Business and Finance Research, 2(2), 63-73.

Taha, R., Šliogerienè, J., Loganathan, N., Jokšienè, I., Shahbaz, M., \& Mardani, A. (2018). The nexus between tax reformation, financial development and economic recovery: the case of Malaysia. Technological and Economic Development of Economy, 24(3), 1258-1279. 